\title{
PERBANDINGAN KEHIDUPAN SOSIAL PEREMPUAN INDONESIA DAN MALAYSIA PADA KUMCER PEREMPUAN, CINTA, DAN KEHIDUPAN
}

\author{
Devi Hari Fitriya Ningsih ${ }^{1}$, Eggy Fajar Andalas ${ }^{2}$ \\ Universitas Muhammadiyah Malang \\ devihari030@webmail.umm.ac.id ${ }^{1}$,eggy@umm.ac.id ${ }^{2}$
}

\begin{abstract}
Abstrak: Permasalahan dan kondisi lingkungan di sekitar akan mempengaruhi kondisi sosial seseorang termasuk kondisi sosial perempuan di Indonesia dan Malaysia. Tujuan dalam penelitian ini yaitu membandingkan kondisi sosial perempuan Indonesia dan Malaysia dalam kumpulam cerita (kumcer) Perempuan, Cinta, dan Kehidupan. Teori sastra bandingan merupakan suatu teori yang digunakan untuk membandingkan beberapa karya sastra dalam aspek sosial kehidupan tokoh dalam karya sastra. Penelitian ini menggunakan metode kualitatif. Sumber data dalam penelitian ini yaitu kumcer Perempuan, Cinta, dan Kehidupan. Pengumpulan data dalam penelitian ini dilakukan dengan cara simak-catat. Teknik analisis data dilakukan dengan cara membaca secara menyeluruh kumpulan cerita (kumcer) Perempuan, Cinta, dan Kehidupan, mengaitkan data yang sudah ditemukan dengan teori sastra bandingan dan mendeskripsikan bagaimana perbedaan kondisi sosial perempuan yang terjadi di Indonesia dan Malaysia. Hasil penelitian ini memperlihatkan kondisi perempuan Indonesia dan Malaysia yang memilki aspek yang sama. Dapat dilihat dari kondisi sosial keduanya, seperti keadaan lingkungan sekitarnya, tuntutan dalam memperjuangkan hidup serta kedudukan laki-laki sebagai superior. Selain itu kondisi sosial perempuan Indonesia dan Malaysia dipengaruhi oleh permasalahan budaya yang berkembang dan pola asuh keluarga yang mempengaruhi kehidupan dan prinsip hidup.
\end{abstract}

Kata kunci: Kondisi Sosial Perempuan, Indonesia, Malaysia, Cerpen, Sastra Bandingan

\begin{abstract}
Environmental problems and social conditions around us will affect someone's social conditions, including the social conditions of women in Indonesia and Malaysia. The purpose of this study was to compare the social conditions of Indonesian and Malaysian women in Perempuan, Cinta, dan Kehidupan's short story collection. In this study, comparative literary theory was used to compare several works of literature in the social aspects of the life of figures in literary w orks. This research uses qualitative methods. The data sources are coming from Perempuan, Cinta, dan Kehidupan's short story collection. Data collections in this study are doing by the listening and take notes method. Data analysis techniques are done by reading thoroughly Perempuan, Cinta, dan Kehidupan's short story collections, linking the data that has been found with comparative literary theory and describing the differences in women's social conditions oc cur in Indonesia and Malaysia. The results of this study show the condition of Indonesian and Malaysian women who have the same aspects. Proven by the social conditions of Indonesia and Malaysia had many same aspects such as the circumstances of the surrounding environment, the demands in fighting for life, and the position of men as superior. Furthermore, the social condition of Indonesian and Malaysian women is affected by growing cultural problems and family parenting that affect life and life principles.
\end{abstract}

Key Words: Women, Social Conditions, Indonesia, Malaysia, Short Stories, Comparative Literature 


\section{Pendahuluan}

Kondisi sosial perempuan di setiap daerah pasti akan berbeda dengan daerah lainnya, apalagi di negara yang berbeda. Kondisi sosial yang dialami perempuan di setiap negara biasanya juga mendapat pengaruh dari nilai-nilai yang berlaku di lingkungan masyarakat tersebut. Kebudayaan juga mempengaruhi suatu kondisi sosial perempuan di suatu negara. (Sukmawati et al., 2017, p. 179). Kondisi sosial yang ada juga menjadi suatu alasan dalam terciptanya karya sastra. Selain itu, pengarang juga menjadi bagian dari kelompok sosial di masyarakat yang memberikan arah di dalam terbentuknya suatu alur dalam penciptaan karya sastra tersebut. Terkadang pengarang terinspirasi dari kondisi sosial perempuan sebagai bentuk fenomena yang terjadi di masyarakat yang direalisasikan dalam hasil karyanya. Dalam penciptaan karya sastra bukan hanya wawasan mengenai masalah sosial politik dan ekonomi tetapi mengenai kenyataan hidup yang terjadi di tengah masyarakat (Puspita, 2019, p. 30). Karya sastra menja di media untuk menggambarkan kondisi sosial perempuan yang terjadi di tengah masyarakat.

Kondisi sosial perempuan di Indonesia akan berbeda dengan kondisi sosial perempuan di Malaysia. Kondisi sosial yang terjadi juga akan mempengaruhi sikap sosial perempuan di kedua negara tersebut. Kondisi sosial yang dialami oleh perempuan juga memberikan pengaruh dalam lingkup masyarakat seperti kebudayaan, nilai-nilai maupun adat istiadat yang ada di kedua negara tersebut (Juanda \& Azis, 2018, p. 72). Kondisi sosial yang dialami oleh perempuan baik di Indonesia mapupun Malaysia juga dapat dipengaruhi oleh faktor ekonomi, politik maupun keadaan geografis negara tersebut. Dampak kondisi sosial perempuan di Indonesia dan Malaysia juga akan mempengaruhi pola pikir para perempuan di negara tersebut.

Melihat kondisi kehidupan sosial yang berbeda ini tentunya para perempuan di kedua negara ini mempunyai cara tersendiri ketika menyelesaikan permasalahan yang mereka hadapi. Perbedaan cara penyelesaian yang dipilih oleh perempuan ini biasanya didasarkan pada ideologi mereka. Hubungan antara konsep hidup atau ideologi dan tindakan manusia sangat erat, oleh karena itu konsep ideologi seseorang dapat menjadi kekuatan yang luar biasa dalam menentukan suatu keputusan (Asri, 2013, p. 71). Seperti kebebasan dalam hidup untuk meyampaikan pendapat kini bisa dilakukan oleh kaum perempuan.

Di dalam kumpulan cerita pendek Indonesia-Malaysia Perempuan, Cinta, dan Kehidupan, pengarang menggambarkan kondisi sosial perempuan di kedua negara tersebut. Dalam kumpulan cerpen ini terdapat dua puluh kisah yang ditulis oleh sepuluh pengarang Indonesia dan sepuluh pengarang Malaysia yang terbit pada tahun 2019. Kumpulan cerita (kumcer) ini menceritakan permasalahan kehidupan sosial perempuan di negara Indonesia dan perempuan di negara Malaysia di mana dalam kedua negara tersebut memiliki perbedaan kehidupan sosial yang dihadapi oleh para perempuan, begitu juga dengan cara perempuan di kedua negara ini dalam menyelesaikan permasalahan kehidupannya. Beberapa permasalahan kehidupan perempuan yang banyak dibicarakan oleh pengarang Indonesia yaitu mengenai permasalahan perlakuan adat dalam memilih pasangan dan kebebasan perempuan dalam menentukan jalan hidupnya (Nafiyah \& Mardikantoro, 2016, p. 22). Seperti dalam kumcer Perempuan, Cinta, dan Kehidupan para pengarang Indonesia banyak mengangkat 
cerita tentang bagaimana perjuangan perempuan dalam menentukan jalan hidupnya.

Berdasarakan dua puluh kisah yang terdapat dalam kumcer Perempuan, Cinta, dan Kehidupan dapat diketahui bagaimana kondisi sosial perempuan yang terjadi di kedua negara tersebut. Peran perempuan dalam menghidupi keluarganya, berjuang untuk pendidikan anaknya hingga cara perempuan mempertahankan rumah tangganya diceritakan secara detail berdasarkan kondisi sosial yang mereka hadapi. Nilai budaya juga menjadi salah satu aspek yang mempengaruhi alur dalam setiap cerita yang ada. Namun pengarang lebih menyorot bagaimana kondisi sosial perempuan yang terjadi di Indonesia dan Malaysia karena banyak menunjukkan perjuangan perempuan dalam mengatasi permasalahan hidupnya.

(Najla, 2021, p. 16) Suatu karya sastra merupakan bentuk gambaran kehidupan sosial masyarakat yang dibuat untuk dipahami dan dinikmati. Permasalahan kondisi sosial perempuan yang terjadi di Indonesia dan Malaysia dianggap sebagai suatu fenomena yang dapat dijadikan sebagai kajian dalam karya sastra. Pengarang melihat fenomena kondisi sosial perempuan di kedua negara tersebut sebagai suatu perbandingan pola pikir bahkan bisa memunculkan kebiasaan baru dalam lingkungan masyarakat di sekitarnya. Cara perempuan dalam menghadapi kondisi sosial yang berbeda di Indonesia dan Malaysia juga dapat dilihat sebagai suatu hasil dari pola pikir perempuan di negara tersebut.

\section{Penelitian Sebelumnya}

Sejauh pencarian yang dilakukan dalam penelitian ini belum ada penelitian yang memakai objek kajian kumcer Perempuan, Cinta, dan Kehidupan, namun terdapat fokus kajian yang sama yang membahas tentang perbandingan kondisi sosial perempuan. Beberapa penelitian yang telah dilakukan antara lain penelitian dari Ramadhani (2019), Hubungan Antara Perbandingan Sosial dengan Distorsi Citra Tubuh Pada Remaja di Surabaya. Hasil penelitiannya diketahui bahwa semakin sering remaja perempuan membandingkan bentuk tubuhnya dengan wanita lain maka semakin tinggi tingkat distorsi citra tubuh yang dialaminya. Penelitian selanjutnya yaitu dilakukan oleh Sakinah (2017), Feminisme: Analisis Perbandingan Ideologi "Cantik" Tokoh Perempuan Pada Dunia Chick-lit; The Debutante Divorcéé (Janda-Janda Gres) Karya Plum Sykes dan Test Pack Karya Ninit Yunita. Hasil penelitian ini menunjukkan bahwa kedua chick-lit ini bertemakan tentang percintaan yang tiada ujungnya dan memiliki konsep "cantik" yang merupakan suatu kodrat seorang perempuan.

Penelitian berikutnya yaitu dilakukan oleh Nasution (2019), Perbandingan Tokoh Perempuan dalam Novel "Amelia" Karya Tere Liye dan "Gadis Pantai" Karya Pramoedya Ananta Toer. Hasil dari penelitian ini yaitu perbandingan tokoh perempuan pada novel Amelia dan Gadis Pantai yang memiliki perubahan sifat sesuai keadaan dan situasi yang ada dalam novel. Penelitian yang terakhir yaitu dilakukan oleh Zakaria (2014) yang berfokus mengenai adanya perbandingan antara konsep kepemimpinan kaum perempuan yang dilihat berdasarkan pandangan Tokoh Aisyiyah dan Tokoh Feminisme yang ada di daerah Malang. Hasil dari penelitian ini yaitu terlihatnya perbedaan yang dilakukan dalam kepemimpinan perempuan Aisyiyah yang selalu memilih lebih mengutamakan kepemimimpinan di lingkup keluarga sedangkan menurut tokoh feminis kesempatan perempuan memimpin di luar lingkup keluarga lebih banyak dan lebih diutamakan. 
Berdasarkan hasil temuan penelitian sebelumnya dapat disimpulkan bahwa penelitian ini belum pernah dilakukan.

Penelitian ini berbeda dengan penelitian lainnya, karena berfokus membahas mengenai perbandingan kondisi sosial, pronsip, dan ideologi perempuan Indonesia dan Malaysia yang terdapat dalam kumpulan cerita pendek Perempuan, Cinta, dan Kehidupan.

\section{Landasan Teori}

Beberapa para ahli yang menganut aliran feminisme sosialis yaitu Charlotte Perkins Gilman dalam karyanya "The ManMade World and Woman and Economic" (dalam Amin, 2013, p. 149) yang mengatakan bahwa kemerdekan kaum perempuan didasarkan pada kemerdekaan ekonomi. Hal itu berarti bahwa kebebasan hak perempuan mutlak ditentukan oleh kebebasan oleh faktor ekonomi. Ditemukan beberapa kasus yang membuktikan bahwa beberapa perempuan dipaksa untuk menikah atau dijual oleh keluarganya karena faktor ekonomi.

Menurut pendapat selanjutnya, Feminisme sosialis merupakan suatu aliran tentang anggapan kontruksi sosial sebagai penyebab adanya ketidakadilan pada perempuan (Andestend, 2020, p. 142). Aliran ini beranggapan bahwa perempuan memiliki kedudukan di bawah laki-laki. Adapula anggapan bahwa aliran ini lahir atas krtitik adanyanya feminisme Marxis.

Berdasarkan prespektif feminisme sosialis, kapitalisme dan patriarki dianggap sebagai ideologi yang menyebabkan adanya penindasan terhadap kaum perempuan (Rahman, 2019, p. 1). Hal ini yang mengakibatkan adanya feminisme sosialis yang digunakan sebagai bentuk penghapusan budaya patriarki dan kapitalisme yang merugikan kaum perempuan. Di dalam kumcer Perempuan, Cinta, dan Kehidupan tokoh perempuan yakin bahwa mereka bisa berkembang dan menjalani kehidupan mereka berdasarkan prinsip dan ideologi yang mereka miliki sehingga mereka beranggapan bahwa perempuan juga dapat bertahan hidup sendiri tanpa bantuan kaum laki-laki.

\section{Metode dan Data}

Penelitian ini menggunakan metode kualitatif. Penelitian kualitatif digunakan untuk menggambarkan bagaimana perbandingan kehidupan sosial perempuan di Indonesia dan Malaysia. Penelitian ini menggunakan teori Sastra Bandingan. Sastra Bandingan merupakan sebuah kajian dari dua karya sastra yang berbeda, baik secara wilayah, kepengarangan, maupun penceritaan sebuah kisah (Anggraini, 2015, p. 64). Kegiatan membangdingan merupakan suatu teknik yang tepat yang digunakan dalam penelitian sosial-budaya. Berdasarkan hal tersebut, penelitian ini digunakan untuk membandingkan secara aspek sosial mengenai kehidupan perempuan di Indonesia dan Malaysia dalam kumcer Perempuan, Cinta, dan Kehidupan.

Sumber data dalam penelitian ini yaitu kumcer Indonesia-Malyasia Perempuan, Cinta, dan Kehidupan yang diterbitkan tahun 2019 dan ditulis oleh sepuluh pengarang Indonesia dan sepuluh pengarang Malaysia. Data dalam penelitian ini berupa keadaan sosial perempuan yang ada di Indonesia dan Malaysia dalam kumcer Perempuan, Cinta, dan Kehidupan yaitu digambarkan melalui dialog antar tokoh dalam kumcer, narasi penggambaran kondisi sosial tokoh perempuan Indonesia dan Malaysia serta perbedaan dalam menghadapi kondisi sosial yang terjadi.

Dalam penelitian ini menggunakan teknik pengumpulan data berupa teknik simak-catat. Di dalam teknik ini dilakukan dengan cara, membaca secara menyeluruh kumcer, memahami isi kumcer dan mencatat hal-hal penting atau data yang sudah 
ditemukan. Analisis data dilakukan dengan cara, pertama membaca secara menyeluruh kumcer Perempuan, Cinta, dan Kehidupan. Kedua mengaitkan data yang sudah ditemukan dalam kumcer dengan metode yang sudah ditentukan yaitu Sastra Bandingan. Ketiga mendeskripsikan bagaimana perbedaan kondisi sosial perempuan yang terjadi di Indonesia dan Malaysia.

Teknik yang digunakan untuk memeriksa keabsahan data dalam penelitian ini yaitu triangulasi sumber data. Triangulasi sumber data dilakukan dengan cara melakukan pengecekan kembali data yang digunakan oleh asisten peneliti. Triangulasi sumber data merupakan cara pengecekan kevalidan data yang diperoleh dengan melihat data dari beberapa sumber yang sejenis dengan penelitian yang telah dilakukan (Hadi, 2016, p. 77).

\section{Hasil dan Pembahasan}

Masyarakat pada umumnya tidak akan terlepas dari kondisi sosial yang terjadi di dalam kehidupan mereka. Interaksi antar sesama individu akan mempengaruhi tingkat kondisi sosial yang dialami. Perempuan sebagai salah satu individu dalam suatu masyarakat memiliki kondisi sosial yang berbeda di setiap daerah bahkan negara. Kondisi sosial perempuan ini juga dipengaruhi oleh kebudayaan yang ada di lingkungan sekitarnya, kondisi geografis serta pola interaksi yang terjadi di masyarakat sekitarnya. Hal ini yang menunjukkan adanya perbedaan kondisi sosial perempuan yang dialami di setiap negara.

Cerpen merupakan salah satu bentuk karya sastra yang digunakan oleh pengarang sebagai media untuk menggambarkan tentang bagaimana kondisi sosial yang dialami oleh kaum perempuan. Para pengarang laki-laki maupun perempuan juga menggunakan dunia perempuan dalam menciptakan sebuah karya sastra (Hayati, 2012, p. 85). Namun, ada beberapa pengarang laki-laki yang memberikan sudut pandang dengan budaya patriarki dalam menggambarkan atau menceritakan tokoh perempuan. Alur cerita yang diciptakan dengan adanya budaya patriarki tersebut secara tidak langsung akan mempengaruhi pandangan masyarakat terhadap kedudukan perempuan di masyarakat. Perempuan akan dianggap memiliki kedudukan di bawah kaum laki-laki yang membuat adanya ketidaksetaraan gender. Selain itu hal ini juga akan memberikan pandangan baru dalam masyarakat tentang citra perempuan yang juga akan berpengaruh pada kondisi sosial perempuan tersebut.

\section{Kondisi Sosial Perempuan di Indonesia dan Malaysia}

Kondisi sosial perempuan di Indonesia akan berbeda dengan kondisi sosial perempuan di Malaysia. Kondisi lingkungan sekitar juga mempengaruhi kondisi sosial perempuan di Indonesia dan Malaysia. Seperti yang terdapat di dalam kumcer "Perempuan, Cinta dan Kehidupan" yang menggambarkan bagaimana kondisi sosial perempuan Indonesia dan Malaysia. Berikut merupakan dialog yang menggambarkan perempuan Indonesia juga melihat kondisi sosial di sekitarnya dalam menentukan keputusan dalam hidupnya.

"Banyak perkawinan teman di lingkungannya yang awalnya manis dan romantis, lalu berantakan, perselingkuhan, kekerasan dan mengambil jalan sendirisendiri (Kaen \& Zakir, 2019, p. 31)"

Keadaan di lingkungan sekitar akan mempengaruhi seseorang dalam mengambil suatu keputusan. Seperti kutipan data di atas dijelaskan bahwa tokoh perempuan dia melihat kondisi sosial tentang pernikahan yang terjadi di lingkungan sekitarnya yang terkesan negatif dan membuat tokoh perempuan ia berpikir berkali-kali untuk mengambil keputusan mengenai pernikahan. 
Seseorang yang sudah mempunyai pola pikir tertentu akan dengan mudah berubah ketika seseorang tersebut menemukan pengaruh yang kuat yang dapat mempengaruhi pemikirannya (Naufal, 2016, p. 3).

Kondisi sosial di atas tidak hanya dialami oleh perempuan Indonesia namun juga dialami perempuan di Malaysia. Hal-hal yang terjadi disekitar kehidupannya akan mempengaruhi tingkat pola pikir kaum perempuan. Seperti kutipan berikut yang mengambarkan bagaimana prinsip perempuan Malaysia dipengaruhi oleh kondisi sosial yang ada disekitanya.

"Saya mencintai Islam. Hangatnya di sini sangat saya rasakan. Begitu saya percaya negara Tuan lebih-lebih lagi. Wanitanya dengan jilbab. Lelakinya yang melindungi. Masjidnya yang tentram. Makannya yang halal. Akhlak negaranya yang terpuji dengan membenarkan Islam bernafas di mana-mana (Kaen \& Zakir, 2019, p. 172)"

Berdasarkan kutipan di atas dapat diketahui bahwa prinsip perempuan dipengaruhi oleh keadaan lingkungan sekitarnya. Lingkungan sosial yang merupakan dasar dari manusia berinteraksi dengan manusia lain menciptakan kondisi dan konvensi yang berlaku di lingkungan tersebut (Khairuddin, 2018, p. 101). Pengaruh lingkungan sekitar akan membuat seseorang menjadi terpengaruh, sehingga jika pengaruh lingkungan itu baik maka hasil yang didapatkan juga baik begitu juga sebaliknya. Seperti yang digambarkan pada kutipan di atas tentang kondisi sosial perempuan Malaysia yang terjadi. Hal tersebut membuktikan bahwa keadaan lingkungan sekitar dapat mempengaruhi kondisi perempuan di Indonesia dan Malaysia.

Kehidupan selalu berkaitan dengan perjuangan. Berjuang menghidupi keluarga pada kenyataannya bisa dilakukan perempuan tanpa mengandalkan bantuan laki-laki. Seperti perjuangan tokoh "ibu" dalam kumcer "Perempuan, Cinta dan Kehidupan" yang menghidupi keluarganya setelah ditinggal suaminya dan dia juga tidak lupa menjalankan tugasnya sebagai ibu meskipun sibuk bekerja seperti pada kutipan di bawah ini.

"Selama ini aku memang jarang dirumah, karena tugas-tugasku yang menuntutku sering ke luar kota. Bahkan juga ke luar negeri. Kedua anakku kutinggal, hanya bersama pembantu sejak suamiku meninggal (Kaen \& Zakir, 2019, p. 134)"

Ketidaksetaraan gender yang dirasakan oleh kaum perempuan nyatanya membuat mereka lebih sadar dan berusaha untuk berjuang demi kesejahteraan hidup mereka. Seperti pada kutipan di atas tokoh perempuan dalam novel berusaha untuk memperjuangkan kehidupan keluarganya dimana tokoh perempuan tersebut merupakan seorang single parrent yang ditutuntut untuk bisa memerankan tugas sebagai seorang ayah dan ibu dalam waktu yang bersamaan. Hal itu membuktikan bahwa perempuan bisa memiliki jiwa superior dan inferior dalam satu waktu yang sama.

Tekanan sosial yang dirasakan perempuan dalam kehidupannya membuat mereka terbiasa untuk melakukan semua hal sendiri. Berdasarkan kebiasaan tersebut perempuan bisa survive di kehidupannya tanpa peran sosok laki-laki dan beberapa perempuan mengaggap bahwa dalam prinsip mereka perempuan bisa memiliki standar status sosial yang sama dengan laki-laki melebihi kodrat awal mereka, seperti pada kutipan di bawah ini.

"Di lain pihak aku begitu congkak, menyebu-nyebut diriku sebagai perempuan karir yang dimata masyarakat derajatnya lebih tinggi dibandingkan dengan derajat ibu rumah tangga (Kaen \& Zakir, 2019, p. 137)" 
Perjuangan perempuan dalam meningkatkan status sosialnya di lingkup masyarakat terkadang memang membuat mereka lupa dengan kodrat mereka. Hal itu dapat dilihat dalam kutipan di atas di mana sosok perempuan tersebut lebih sombong karena merasa memiliki kedudukan yang lebih tinggi daripada perempuan di lingkungan sekitarnya yang hanya menjadi seorang ibu rumah tangga. Perjuangan perempuan dalam menyetarakan gender memang hal yang wajar dan normal hanya saja mereka juga perlu mengingat bahwa mereka juga memiliki kodrat sebagai sosok perempuan yang harus memperhatikan kehidupan keluarga mereka sebagai seorang ibu rumah tangga.

Kasta perempuan sebagai ibu rumah tangga di masyarakat terkadang menjadi sesuatu hal yang dianggap sebelah mata. Pada kenyataannya kodrat perempuan memang mengurus kehidupan rumah tangga tetapi hal itu tidak menutup kemungkinan bagi perempuan untuk melakukan sesuatu hal yang biasa dilakukan oleh laki-laki. Perempuan bebas melakukan pekerjaan di sektor industri namun perempuan juga harus menyadari kodratnya yaitu kewajibannya dalam sektor domestik yaitu keluarga. Pilihan tersebut terkdang memang menjadi dilema bagi kaum perempuan seperti kutipan yang ada di bawah ini.

"Aku sudah menemukan jawaban-Nya melalui sholat istikharah yang kulakukan satu minggu berturut-turut. Jawbannya itu: NO!- demi keutuhan jiwa anak bungsuku dan juga si sulung yang baru akan beranjak remaja (Kaen \& Zakir, 2019, p. 138)"

Berdasarkan kutipan tersebut dapat dilihat bahwa tokoh perempuan memilih untuk melakukan kewajibannya sebagai seorang ibu yaitu mengurus anak-anaknya daripada meningkatkan kariernya di sektor industri. Tokoh perempuan tersebut menganggap bahwa ia memiliki tugas utama untuk menjaga kualitas psikologi anak- anaknya dengan cara merawat langsung mereka tanpa bantuan sosok pembantu. Hal itu dilakukan karena tokoh perempuan sadar bahwa dia bukan hanya harus memberikan figur seorang ibu tetapi juga figur seorang ayah.

Perempuan juga harus memiliki prinsip hidup yang kuat agar tidak mudah terpengaruh dengan hal-hal yang terjadi di masyarakat. Setiap keputusan yang diambil harus bisa memberikan dampak yang signifikan agar semua perjuangan yang dilakukan tidak sia-sia sebagai sosok perempuan yang berusaha memperjuangkan kesetaraan gender tanpa melupakan kewajiban utamanya dalam keluarga. Seperti halnya pada kutipan yang ada di bawah ini dimana tokoh perempuan yang memutuskan untuk pindah bekerja dengan membawa serta keluarganya agar dia tetap bisa mengurus keluarganya tanpa meninggalkan kewajibannya untuk mencari nafkah.

"Tiga bulan kemudian aku pindah kerja di sebuah perusahaan yang juga multinasional dengan kedudukan setara. Pos-ku di Australia, kedua anakku dan mamiku kubawa serta: tiga Pelita Hati! (Kaen \& Zakir, 2019, p. 140)”

Menjadi sosok perempuan mandiri memang menyenangkan. Perempuan memiliki kekuatan yang sama besarnya dengan laki-laki. Bahkan banyak ditemukan perempuan memiliki pekerjaan atau jabatan yang lebih tinggi daripada laki-laki di sektor industri. Adapula perempuan yang bisa melakukan pekerjaan kasar seperti bertani ataupun perempuan yang memiliki intelektual tinggi hingga bisa menjadi pemimpin.

Kedudukan perempuan juga setara dengan laki-laki sehingga budaya patriarki juga bisa dianggap sudah tidak berlaku bagi perempuan. Seperti pada data di atas yang menunjukkan bahwa kaum perempuan bisa melakukan hal-hal yang biasa dilakukan oleh kaum laki-laki. Tokoh "perempuan" dalam 
data di atas menunjukkan bagaimana ia bekerja keras demi menghidupi keluarganya . Kerja keras bukan berarti bekerja sampai tuntas lalu berhenti, namun istilah kerja keras mengarah pada visi besar yang harus dicapai untuk kebaikan manusia dan lingkungannya (Sulastri \& Alimin, 2017, p. 158).

Namun seiring berkembangnya jaman kini kedudukan perempuan mulai diakui dan perempuan memiliki hak yang sama dengan laki-laki. Kaum perempuan juga membuat gerakan kesetaraan gender yang membuktikan bahwa perempuan bisa berkembang tanpa bantuan kaum laki-laki seperti pada kutipan dialog di bawah ini.

"Ya semua kami lakukan demi keturunan kami. Mudah-mudahan mereka dapat menjadi lebih baik dari kami. Di seluruh dunia biaya pendidikan sangat tinggi dan memang mahal, buka? (Kaen \& Zakir, 2019, p. 51)"

"He..he..he.. bettul. Tapi kalau mau kaya lebih canggih jika mempermainkan hew an-hew an yang dalam kelolaan kami. Jika berada di puncak seperti kedudukan saya, ada saja akal untuk korupsi, untuk main-main dengan hukum dan dapat harta secara aneh.. (Kaen \& Zakir, 2019, p. 52)"

Dari data diatas sudah ditunjukkan bahwa kaum perempuan bisa berjuang untuk menghidupi keluarganya. Sosok orang tua akan melakukan apapun untuk memperjuangkan kehidupan anaknya agar lebih baik dari kehidupan mereka, utamanya dalam aspek pendidikan. Karena pendidikan dianggap sebagai pondasi awal untuk kesuksesan. Kondisi sosial yang terjadi di lingkungan sekitar juga akan mempengaruhi tingkat keberhasilan seseorang karena interaksi antar sesama juga akan menumbuhkan sikap saling menghargai dan menghormati. Pendidikan dianggap sebagai suatu kekuatan tersendiri bagi perempuan (Wati \& Sumartini, 2019, p. 177).
Perempuan di Indonesia nampaknya juga bisa membuktikan bahwa kaum perempuan bisa bertahan tanpa bantuan kaum laki-laki. Hal ini juga ditunjukkan oleh perempuan di Malaysia seperti pada kutipan berikut.

"Sejak itu ibu sendirian membesarkan
kami tiga beradik. Ibu juga yang berusaha
keras mengerjakan sebidang tanah
bendang, yang ditinggalkan ayah untuk
kami (Kaen \& Zakir, 2019, p. 185)"
"Sungguh ibu bekerja kuat demi kamu
adik-beradik (Kaen \& Zakir, 2019, p.
187)"

Perempuan yang memiliki status sebagai single parrent harus memiliki jiwa yang lebih kuat dalam memperjuangkan kehidupan keluarganya. Hal itu dijelaskan dalam kutipan di atas di mana perjuangan tokoh perempuan yang menggantikan tugas suaminya. Menjadi sosok figur ayah dan ibu dalam satu waktu yang bersamaan merupakan suatu perjuangan yang tidak mudah. Perempuan tidak hanya dituntut untuk bisa menjalakan tugasnya sebagai ibu rumah tangga tetapi juga menjadi seorang ayah yang harus bekerja keras untuk mencukupi kebutuhan keluarganya.

Terlepas dari perjuangan untuk menyetarakan gender, perjuangan yang dilakukan oleh tokoh perempuan dalam novel juga dilakukan sebagai bentuk untuk mempertahankan hidup. Terlebih lagi bagi sosok perempuan yang harus berjuang sendirian demi keluarganya. Tidak adanya sosok figur laki-laki membuat perempuan harus lebih bisa diandalkan dalam segala aspek kehidupan baik dalam sektor industri maupun domestik atau keluarga. Selain itu fokus penting yang harus diperhatikan oleh perempuan yaitu bidang pendidikan. Perjuangan perempuan dalam bidang pendidikan dapat di lihat dalam kutipan data di bawah ini. 
"Setiap bulan duit hasil kebun, walaupun sekadar RM20, ibu masukkan di bank. Duit itu untuk masa depan kami. Untuk persekolahan kami. Sebab itu mahu kami menimba ilmu sebanyak-banyaknya (Kaen \& Zakir, 2019, p. 187)"

"Kata ibu hanya melalui pendidikan, kami dapat membina tembok yang dapat membentengi diri kami, sebab itu ibu tidak lokek dan tidak ralat terus berbudi kepada tanah demi mendapatkan rezeki (Kaen \& Zakir, 2019, p. 188)"

Selain dituntut untuk bekerja dan menjadi ibu rumah tangga, beberapa perempuan juga dituntut untuk memiliki iltelektual yang tinggi. Pendidikan merupakan suatu hal yang bisa mencerminkan kualitas seseorang. Perempuan yang memiliki pendidikan bagus maka dia akan lebih dihargai oleh laki-laki. Tidak dapat dipungkiri bahwa laki-laki pada dasarnya memiliki kedudukan lebih tinggi dibanding perempuan tetapi hal itu tidak bisa digunakan sebagai alasan untuk tidak mengembangkan diri.

Dari dua data kutipan diatas dijelaskan bagaimana perjuangan sosok ibu untuk pendidikan anak-anaknya. Tokoh perempuan tersebut berjuang mencari uang untuk membiayai pendidikan anaknya agar mereka mendapatkan pendidikan layak dan tidak disepelekan lagi oleh kaum laki-laki. Berbekal pendidikan yang layak, perempuan juga bisa membangun benteng kehidupan yang setara dengan laki-laki. Menjadi perempuan yang memiliki prinsip dan teguh dalam penderiannya merupakan salah satu tujuan pendidikan dalam memperjuangkan kesetaraan gender, seperti kutipan sebagai berikut.

"Jangan begitu nak, jangan berkira, jangan kedekut kalau untuk tujuan ilmu. Belajarlah setinggi mana yang kamu nak. Dengan ilmu itu kamu mesti bina tembok kamu sendiri. Kamu mesti kuat. Kamu mesti cekal. Lihat sekeliling, kamu mesti buat persediaan untuk masa depan (Kaen \& Zakir, 2019, p. 191)"

Jika dilihat berdasarkan kutipan di atas, sosok perempuan yang berada di Malaysia juga bisa berjuang menghidupi keluarganya tanpa bantuan laki-laki. Kondisi ini dapat membongkar kebudayaan patriarki yang pernah berkembang. Budaya patriarki dianggap sebagai suatu kebudayaan yang negatif bagi perempuan. Hal ini karena dalam pandangan masyarakat perempuan dianggap memiliki derajat lebih rendah dari laki-laki sehingga akan ada banyak batasan saat perempuan ingin melakukan sesuatu. Batasan-batasan inilah yang akhirnya menyadarkan perempuan bahwa mereka harus memperjuangkan hak mereka dan memperjuangkan kedudukan mereka sebagai kaum perempuan.

Menurut pandangan feminisme, kaum perempuan memiliki hak, kewajiban serta kesempatan yang sama dengan kaum lakilaki (Muliana, 2016, p. 2-3). Berdasarkan ungkapan di atas dapat disimpulkan bahwa kaum perempuan mempunyai prinsip hidup seperti yang digambarkan dalam kondisi sosial perempuan di Indonesia dan Malaysia pada kutipan di atas.

Perempuan yang bekerja dalam kehidupan berumah tangga dianggap ingin menyaingi kaum laki-laki sebagai kepala keluarga yang bertugas menafkahi keluarganya. Padahal kaum perempuan itu hanya berniat untuk membantu meringankan beban laki-laki dalam kehidupan rumah tangga. Seperti yang tergambarkan pada kutipan di bawah ini.

"Niat baik Ranti untuk menyediakan payung sebelum hujan pada saatnya menjadi sumber pertengkaran dengan Danang. Alih-alih menghargai usaha Ranti, sang suami malah menuduh Ranti sedang melakukan persaingan. Ranti dianggap tidak menghargai pekerjaan dan penghasilannya yang sudah sangat baik (Kaen \& Zakir, 2019, p. 91)” 
Kondisi sosial yang terjadi saat perempuan yang memiliki penghasilan sendiri dianggap ingin menyaingi suaminya, dan hal ini yang akan menimbulkan keinginan kaum laki-laki untuk selalu bisa unggul di atas perempuan. Hal ini membuat perempuan dianggap menyalahi kodrat karena berusaha untuk menyaingi kedudukan laki-laki. Namun kini perempuan juga memiliki hak dan kedudukan yang setara dengan laki-laki tanpa harus meninggalkan kodratnya sebagai perempuan. Seperti data di atas bahwa tokoh "Ranti" tetap melakukan kewajibannya sebagai seorang istri dan ibu namun juga turut membantu dalam mencukupi kebutuhan keluarga dari hasil pekerjaannya namun sang suami menganggap bahwa tokoh "Ranti" ingin menyaingi dirinya sebagai suami dalam aspek pekerjaan. Masyarakat memiliki dua pandangan terhadap status wanita sebagai istri yaitu di satu sisi menjamin hak yang sama dalam hukum dan masyarakat antara suami-istri, di sisi lain dinyatakan bahwa suami berperan di sektor publik dan istri berperan di sektor privat atau di rumah saja (Martha, 2010, p. 225).

Ranti tak sempat mengoyak-ngoyak hati dengan kemarahan yang timbul begitu saja setelah melihat mereka berdua. Ia harus berpikir rasional, berusaha mencari tahu keadaan suami dan sahabatnya yang sedang asyik mengarungi dunia lain (Kaen \& Zakir, 2019, p. 93)"

Konflik yang timbul dalam sebuah kehidupan rumah tangga terjadi akibat adanya perasaan tidak nyaman ataupun tertekan. Kondisi sosial seperti ini digambarkan pada tokoh "Suami Ranti” yang tega berselingkuh dengan sahabat istrinya sendiri karena dia merasa tidak nyaman dan merasa tersaingi karena istrinya mempunyai penghasilan sendiri yang sebenarnya hanya untuk membantu perekonomian keluarganya bukan berniat untuk menyaingi suaminya. Perilaku yang dilakukan erat kaitanya dengan permasalahan kemanusiaan yang dihadapi oleh tokoh perempuan dapat berupa: kesewenang-wenangan, kesetiaan, pengorbanan, dan cinta (Wahyuningtiyas, 2019, p. 68). Kehidupan rumah tangga di Indonesia pada umumnya masih banyak terjadi ketidakadilan gender terutama bagi kaum perempuan. Hal ini yang masih sering dirasakan oleh perempuan Indonesia dalam kehidupan berumah tangga yang masih menganggap laki-laki sebagai superior. Padahal perempuan juga memiliki hak dan kedudukan yang sama dengan laki-laki. Hal itu juga dirasakan oleh perempuan di Malaysia seperti pada kutipan berikut.

"Ya, sememangnya istrinya seorang dewi yang diturunkan dari syurga untuknya. Tidak ada salah dan cela istrinya di mata dan di hatinya. Tetapi apabila Natasya bertanya mengapa dia perlu mengawini wanita lain sedangkan istrinya sudah begitu sempurna baginya, dia memandang mata Natasya yang bergemerlapan itu. saya tidak tahu itulah jawabannya (Kaen \& Zakir, 2019, p. 164)"

Seorang laki-laki akan selalu berusaha untuk berada di posisi lebih tinggi dari perempuan. Dengan adanya hal ini maka laki-laki merasa bebas melakukan apa saja tanpa batasan yang hal ini bertolak belakang dengan nasib perempuan yang hanya sebagai inferior dalam kehidupan bermasyarakat. Masalah sosial yang muncul berkaitan dengan hidup dan kehidupan manusia, serta kemanusiaan itu sendiri (Susanti, 2013, p. 714).

Problematika mengenai kedudukan gender mengahantui para perempuan dari dulu hingga sekarang. Hal itulah yang sering terjadi pada perempuan di Malaysia.

Pandangan masyarakat akibat adanya budaya patriarki memposisikan kaum lakilaki sebagai superior dan kaum perempuan subordinat (Susanto, 2015, p. 122). 
Pembatasan hak yang didapatkan oleh perempuan membuat mereka dianggap lemah dan hanya bisa mengandalkan pihak lakilaki, sedangkan pada dasarnya kaum perempuan juga bisa melakukan apa yang biasa dilakukan oleh kaum laki-laki. Kebudayaan patriarki ini juga menjadi salah satu penyebab terjadinya kesenjangan sosial dan ketidakadilan gender antara kaum perempuan dengan kaum laki-laki.

Dalam kumcer "Perempuan, Cinta dan Kehidupan" kondisi sosial tokoh perempuan di Indonesia juga digambarkan melalui konflik yang terjadi di kehidupan mereka. Seperti pada kutipan dialog dibawah ini.

"Ibuku biasanya bersikap lembut, penuh kasih sayang, tiba-tiba berubah menjadi pemberang (pemarah) (Kaen \& Zakir, 2019, p. 3)"

"Kalau kalian mati semua, ibu ndak ada beban. Uang pensiun ayahmu kan cuma seupil (Kaen \& Zakir, 2019, p. 4)"

Tekanan sosial yang didapatkan oleh tokoh perempuan di Indonesia seperti pada kutipan di atas biasanya bisa memperngaruhi kondisi psikologis perempuan tersebut. Merasa mendapatkan banyak permasalahan di hidupnya membuat tokoh perempuan tersebut frustasi yang akhirnya mempengaruhi kualitasnya dalam menjaga keluarganya. Emosi yang tidak stabil membuat tokoh perempuan itu melampiaskan kemarahannya kepada anakanaknya.

Hal lain yang terjadi akibat tekanan kondisi sosial perempuan di Indonesia yaitu berujung pada penyiksaan terhadap anggota keluarganya terutama anaknya. Hal itu karena mereka menganggap semua tekanan yang mereka dapatkan ini berasal dari anakanaknya, seperti pada kutipan berikut ini.

"Ya benar sekarang ibuku pemarah dan galak, tapi ia bukan lonte, bukan pelacur (Kaen \& Zakir, 2019, p. 5)"
"Setiap hari ibuku memaki-makiku sambil memukuli tubuhku dengan rotan (Kaen \& Zakir, 2019, p. 8)"

Dari kutipan dialog di atas dapat diketahui bahwa kondisi sosial perempuan Indonesia dipengaruhi oleh konflik atau permasalahan-permasalahan yang terjadi di kehidupannya. Kondisi sosial yang dialami seseorang juga akan mempengaruhi keadaan psikologi orang tersebut. Jika kondisi sosial yang dialaminya memang cenderung sulit dan membebani maka secara tidak langsung akan bisa merubah tingkah laku bahkan pola pikir orang tersebut. Dalam kehidupan berumah tangga akan ada banyak perbedaan yang terjadi mulai dari perbedaan pola pikir, gaya dan kebiasaan, sifat dan tabiat, tingkat ekonomi dan pendidikan serta perbedaan lainnya yang akan mempengaruhi tingkat kondisi sosial keluarga tersebut (Haryanie et al., 2017, p. 101). Permasalahan yang terjadi di kehidupannya akan dianggap sebagai beban dan akhirnya bisa membuat kondisi sosialnya berubah sesuai dengan apa yang dia rasakan. Hal itu yang banyak terjadi pada perempuan Indonesia.

Kondisi sosial yang berubah akibat permasalahan yang terjadi juga dapat memberikan dampak yang buruk seperti tekanan hingga menyebabkan kematian seperti yang dialami oleh tokoh "ibu" dalam kutipan dialog berikut ini.

"Setahun kemudian ibuku meninggal dalam kondisi menyedihkan, akibat kanker yang menyerang rahimnya (Kaen \& Zakir, 2019, p. 16)"

Dari dialog tersebut menggambarkan bahwa beban sosial yang dialami tokoh perempuan dapat mempengaruhi kondisi fisik yang memburuk karena ekonomi dan status sosial yang dialami. Tekanan yang dirasakan akibat kondisi sosial yang sedang terjadi pada seseorang pada kenyataannya akan merubah kehidupan orang tersebut. Tokoh "ibu" meninggal karena penyakit 
kanker yang dideritanya dan juga karena faktor tekanan kondisi sosial yang terjadi padanya. Perempuan sebagai seorang istri selalu dihadapkan pada tekanan-tekanan kultural yang ada di masyarakat baik yang berasal dari asumsi perempuan itu sendiri maupun dari pihak keluarga yang memarjinalkan posisinya (Budita, 2015, p. 2). Tekanan akibat permasalahan yang dialami perempuan Indonesia berakibat pada kondisi sosial mereka.

Pada dasarnya perempuan juga memiliki idologi kuat dan prinsip hidup yang tinggi. Perempuan juga memiliki hak yang sama untuk bebas berpendapat. Seperti kutipan dialog dibawah ini yang menggambarkan perempuan juga memiliki ideologi dan prinsip hidup.

"Perempuan egois yang merasa pintar dan mau menang sendiri seakan tidak peduli dengan orang lain selain dirinya (Kaen \& Zakir, 2019, p. 34)"

"Tetapi memang dia tidak memerlukan seorang lelaki nampaknya. Dia kan sangat mandiri (Kaen \& Zakir, 2019, p. 35)"

Perempuan yang memiliki prinsip dan intelektual tingi cenderung merasa lebih mandiri dan tidak membutuhkan figur lakilaki di kehidupannya. Hal itu dijelaskan dalam dua kutipan di atas bahwa tokoh perempuan tersebut yakin akan kemampuan yang dimilikinya sendiri sehingga dia bisa melakukan apapun yang dia inginkan. Tokoh perempuan tersebut menganggap bahwa jika dia bisa melakukan semuanya sendiri secara otomatis dia sudah tidak membutuhkan sosok laki-laki lagi dalam keidupannya.

Teguhnya pendirian dan prinsip yang dimiliki tokoh perempuan Indonesia juga dijelaskan dalam kutipan di bawah ini dimana dalam kasus percintaan tokoh perempuan tidak selemah yang dipikirkan. Para tokoh perempuan nyatanya bisa terlihat baik-baik saja dengan segala konflik percintaan yang sedang mereka alami.
"Lanny tidak akrab dengan Notty tetapi dia melihat ketegasan dan sikap Notty selalu beralasan dalam berargumen, penuh logika dan pemikiran yang jelas. Notty pun tidak cengeng, tidak mudah cemberut ataupun merajuk, sikap yang sering ditemuinya dalam pertemanan dengan perempuan lain. Lanny mengakui kepintaran Notty dan dia menganggap itu bukan sikap kesombongan tetapi sikap tegas yang berpijak pada kebenaran yang logis (Kaen \& Zakir, 2019, p. 36)"

"Tidak banyak perempuan mampu memahami ini, meski perjuangan telah dilew ati, dan perempuan sudah keluar dari cangkangnya untuk menikmati hasil yang mereka perjuangkan, tetapi menurut pendapat Lanny asih banyak perempuan yang mengerami pemikiran yang subjektif dipenuhi rasa suka atau tidak suka dengan pemikiran kurang kritis (Kaen \& Zakir, 2019, pp. 36-37)”

Perempuan dan laki-laki sejatinya memiliki kedudukan yang setara. Pemahaman yang beredar di masyarakat pada umumnya memang kedudukan perempuan selalu berada di bawah laki-laki, sehingga perempuan memiliki batas-batas tertentu dalam melakukan sesuatu. Namun sekarang tidak lagi, karena ideologi itu sudah berubah dan sekarang perempuan meiliki kedudukan dan hak yang sama dengan kaum laki-laki seperti kebebasan dalam berpendapat.

Seperti beberapa data yang sudah ada yang menunjukkan tokoh "Notty" digambarkan sebagai wanita yang yang memiliki ideologi kuat dan prinsip yang kuat. Dia beranggapan bahwa perempuan juga memiliki hak untuk menyampaikan pendapat. Hal ini berarti bahwa perempuan memiliki kesetaraan kedudukan dengan lakilaki. Citra perempuan modern ditandai bahwa dia adalah wanita yang berpendidikan, rasional, tidak statis dan ingin maju serta tidak bergantung pada kaum laki-laki (Margono, 2015, p. 3). Bagi perempuan Indonesia prinsip hidup adalah bagian 
penting yang akan mempengaruhi keberlanjutan kehidupan mereka.

Kondisi suatu masyarakat akan dipengaruhi oleh kebudayaan dan adat istiadat yang berkembang di lingkungan masyarakat tersebut. Banyak faktor yang akan membuat perubahan kondisi sosial di masyarakat seperti nilai sosial, organisasi susunan, lapisan masyarakat, kekuasaan serta interaksi sosial (Lumintang, 2015, p. 1). Perubahan kondisi sosial yang terjadi juga dapat disebabkan oleh permasalahpermasalahan yang terjadi di kehidupan mereka seperti kondisi sosial perempuan di Malaysia. Pengarang di Malaysia menggunakan karya sastra sebagai media dalam menyampaikan nilai-nilai atau pesan akibat suatu permasalahan yang terjadi di kehidupan nyata dan dikemas dalam tatanan bahasa yang menarik. Berbagai permasalahan yang telah dikonstruksikan oleh kebudayaan dan digambarkan dalam peran tokoh perempuan yang ada di karya sastra akan memberikan gambaran tentang kedudukan perempuan Malaysia dan kehidupannya.

Salah satunya tentang kebudayaan perjodohan di Malaysia yang masih percaya dengan simbol dari orang-orang jaman dahulu. Tradisi perjodohan di Malaysia ini masih didasarkan pada adanya simbol berupa "air", "angin" dan "api" untuk setiap calon pasangan yang akan menikah seperti yang digambarkan pada kutipan berikut.

"Mana kamu tahu? Kata opah dia dah tengok kamu serasi dengan Zauyah. Dia "air" dan kamu "angin", sama-sama sejuk, aman damai rumah tangga kamu nanti (Kaen \& Zakir, 2019, p. 146)"

"Hanya dengan membilang huruf Jawi pada nama seseorang dan mendapatkan maklumat tarikh lahir, representasi anasir alamiahnya dapat ditentukan. Aku "angina", Zauyah "air", dan Zika "api". Entah dari mana mereka belajar dan siapa mahaguru mereka, aku tidak tahu (Kaen \& Zakir, 2019, p. 147)"

Sebagian orang sesepuh di Malaysia masih mempercayai simbol dari aura seseorang dalam menentukan jodoh. Seperti kutipan pada data di atas dapat diketahui bahwa tokoh "opah" atau nenek masih percaya bahwa pernikahan harus dilihat terlebih dahulu dari aura setiap pasangannya yang diibaratkan dengan "air", "angin" dan "api". Mereka percaya bahwa jika "air" dan "angin" bersatu maka rumah tangganya akan tentram sedangkan jika "angin" dan "api" bersatu maka akan banyak terjadi hal-hal buruk dalam rumah tangganya nanti.

Kepercayaan dalam aspek perjodohan ini dinilai sebagai suatu nilai kebudayaan masyarakat sekitar. Dalam suatu kebudayaan akan ada konsep-konsep berupa pola maknamakna yang dilestarikan secara historis yang berwujud simbol-simbol yang digunakan untuk berkomunikasi, melestarikan kebudayaan dan adat istiadat dan mengembangkan pengetahuan mereka tentang kehidupan (Pertiwi, 2018, p. 1). Kebudayaan seperti itu masih berkembang di kehidupan sosial perempuan yang ada di Malaysia.

Selain dalam aspek perjodohan, kedudukan perempuan juga harus memperhatikan tingkat pola asuh dalam keluarganya. Dalam hidup berumah tangga pola asuhan orang tua sangat berpengaruh dalam perkembangan anak. Pola asuh yang baik akan mendorong terciptanya kepribadian yang baik pula dalam diri anak namun jika pola asuhnya kurang baik maka juga akan berpengaruh dalam perkembangan sang anak seperti pada kutipan berikut.

"Nak baca apa? Kita tak tahu nak baca apa. Papa tak pernah ajar (Kaen \& Zakir, 2019, p. 227)”

Didikan orang tua sangat berpengaruh dalam kondisi sosial anak-anaknya. Ajaran yang baik akan memberikan hasil yang baik 
dan juga akan membangun karakter dan moral yang berkualitas bagi anak. Freud (dalam Purwaningrum, 2016, p. 15) menjelaskan bahwa semua kegiatan dan tingkah laku manusia dipengaruhi oleh pergolakan tak sadar yang muncul dari perepresian berbagai peristiwa pada masa kanak-kanak. Karakter anak akan terbentuk dari pola asuhan yang diberikan. Oleh karena itu perempuan di Malaysia juga harus memperhatikan tingkat pola asuh dalam keluarganya.

\section{Simpulan}

Kondisi sosial merupakan suatu bentuk keadaan yang dialami oleh seseorang akibat adanya pengaruh dari lingkungan sekitarnya. Fenomena yang terjadi di kehidupan sekitarnya serta permasalahan yang mereka hadapi juga akan mempengaruhi kondisi sosial mereka. Kondisi sosial setiap orang akan berbeda seperti kondisi sosial perempuan di Indonesia dan Malaysia.

Kondisi perempuan di Indonesia dan Malaysia dipengaruhi oleh beberapa aspek antara lain keadaan lingkungan sekitarnya, tuntuntan dalam memperjuangkan hidup serta kedudukan laki-laki sebagai superior. Selain itu kondisi sosial perempuan Indonesia dan Malaysia dipengaruhi oleh permasalahan budaya yang berkembang dan pola asuh keluarga yang mempengaruhi kehidupan dan prinsip hidup. Kondisi sosial yang dialami oleh perempuan Indonesia dan Malaysia ini digambarkan melalui dialog antar tokoh.

\section{Daftar Pustaka}

Andestend, A. (2020). Feminisme Sosialis di Dalam Novel Mencari Perempuan yang Hilang Karya Imad Zaki. Jurnal Ilmiah Korpus, 4(2), 138-147. https://doi.org/10.33369/jik.v4i2. 8022

Anggraini, N. (2015). Pergeseran Nilai Budaya Minangkabau Dalam Novel Dari Surau Ke Gereja Karya Helmidjas Hendra Dan Novel Persiden Karya
Wisran Hadi (Tinjauan Sastra Banding). Dinamika UMT, 1(1), 63-70. https://doi.org/10.31000/dinamika.v1i1. 509

Asri, Y. (2013). Refleksi Ideologi Wanita Minangkabau Dalam Novel Negeri Perempuan Karya Wisran Hadi. Humaniora, 25(1), 69-81. ttps://doi.org/10.22146/jh. 1814

Budita, A. K. (2015). Tindakan Sosial Penderita Kanker Serviks Terkait Peran Sebagai Istri Dalam Rumah Tangga (Undergraduate Thesis). http://repository.unair.ac.id/16055/

Hadi, S. (2016). Pemeriksaan Keabsahan Data Penelitian Kualitatif Pada Skripsi. Jurnal Ilmu Pendidikan Universitas Negeri Malang, 22(1), 109874. http:/journal. um.ac.id/index.php/jip/art icle/view/8721/4194

Haryanie, S. W., Filiani, R., \& Hanim, W. (2017). Dampak Perceraian Orang Tua Terhadap Emosi Anak (Studi kasus pada dua anak yang memiliki orang tua yang bercerai di SDN Gembong I Kab. Tangerang). Insight: Jurnal Bimbingan dan Konseling 2(1), 100-106. https://doi.org/10.21009/INSIGHT.021. 17.

Hayati, Y. (2012). Dunia Perempuan Dalam Karya Sastra Perempuan Indonesia (Kajian Feminisme). Humanus 11(1), 85-93. https://doi.org/10.24036/jh.v11i1.626

Juanda, J., \& Azis, A. (2018). Penyingkapan Citra Perempuan Cerpen Media Indonesia: Kajian Feminisme. LINGUA: Journal of Language, Literature and Teaching, 15(2), 71. https://doi.org/10.30957/lingua.v15i2.4 78

Kaen, S., \& Zakir, S. M. (2019). Perempuan, Cinta, dan Kehidupan: Kumpulan Cerpen Indonesia-Malaysia. Jakarta: Yayasan Pustaka Obor Indonesia.

Khairuddin, F. (2018). Representasi Citra 
Perempuan dan Relasinya Terhadap Nilai Religiusitas Dalam Novel Air Mata Tuhan Karya Aguk Irawan M . N. Prosiding SENASBA (Seminar Nasional Bahasa dan Sastra) 100-107. http://researchreport.umm.ac.id/index.php/SENASBA SA

Lumintang, J. (2015). Pengaruh Perubahan Sosial Terhadap Kemajuan Pembangunan Masyrakat Di Desa TaraTara I. E-Journal Acta Diurna, 4(2), 14.

https://ejournal.unsrat.ac.id/index.php/a ctadiurnakomunikasi/artic le/view/7256

Nafiyah, K., \& Mardikantoro, H. B. (2016). Permasalahan Perempuan Dalam Kumpulan Cerpen Malam Sepasang Lampion Karya Triyanto Triwikromo. Seloka: Jurnal Pendidikan Bahasa Dan Sastra Indonesia, 5(1), 1-7. https://doi.org/10.15294/seloka.v5i1.12 739

Margono, A. (2015). Perjuangan Kesetaraan Gender Tokoh Wanita Pada NovelNovel Karya Abidah El Khalieqy. Seloka : Jurnal Pendidikan Bahasa dan Sastra Indonesia Abstrak. 4(1), 1-8. https://doi.org/10.15294/se loka.v4i1.68 50

Martha, N. U. (2010). Citra Istri Dalam Kumpulan Novelet Dunia Tanpa Warna Karya Mira W (Sebuah Kajian Sastra Feminis). Muwazah 2(1) 225-234. http://e-

journal.iainpekalongan.ac.id/index.php/ Muwazah/article/view/20

Muliana, D. (2016). Citra Perempuan Dalam Novel Tragedi Gadis Parijs Van Java Karya Ganu Van Dort. Jurnal Humanika 16(1). http://ojs.uho.ac.id/index.php/HUMAN IKA/article/view/687

Najla, F. (2021). Pergundikan Perempuan Jawa Dalam Novel Gadis Pantai Karya Pramoedya Ananta Toer.
(Undergraduate Thesis). https://eprints.umm.ac.id/74210/

Nasution, Y. A. (2019). Perbandingan Tokoh Perempuan dalam Novel "Amelia " Karya Tere Liye dan " Gadis Pantai" Karya Pramoedya Ananta Toer. Jurnal Ilmiah Pendidikan Bahasa Dan Sastra Indonesia, 1(1), 30-41. https://ejurnal. univalabuhanbatu.ac.id/i ndex.php/kontras/artic le/view/37

Naufal, M. (2016). Pergeseran Pola Pikir Tokoh Utama Dalam Novel Ketika Elang Kembali Ke Sarang: Kajian Sosiologi Sastra. (Undergraduate Thesis). http://lib. unnes.ac.id/28712/

Pertiwi, A. D. (2018). Representasi Kepercayaan Masyarakat Jawa dalam Karya Akmal Nasery Basral (Kajian Interpretatif Simbolik Clifford Geertz). Sapala, 5(1), 1-10. https://jurnalmahas iswa.unesa.ac.id/ind ex.php/jurnal-sapala/artic le/view/29570 Purwaningrum, L., \& Nas, H. S. (2016). Pengaruh Pola Asuh Permisif Terhadap Perkembangan Kepribadian Tokoh Utama Novel Mendung Tak Bermalam Karya Abu Umar Basyier: Kajian Psikologi Sastra. Lingua, 12(1), 13-24. https://journal.unnes.ac.id/nju/index.ph p/lingua/artic le/view/8688/5716

Puspita, Y. (2019). Stereotip Terhadap Perempuan dalam Novel-Novel Karya Abidah El Khalieqy: Tinjauan Sastra Feminis. Jurnal Ksatra, 1(1), 29-42. https://doi.org/10.52217/ksatra.v1i1.7

Rahman, M. T. (2019). Pemikiran Feminisme Sosialis dan Eksistensialis. (Teaching Resource). http://digilib.uinsgd.ac.id/id/eprint/216 43

Ramadhani, N. M. (2019). Hubungan Antara Perbandingan Sosial Dengan Distorsi Citra Tubuh Pada Remaja Perempuan Di Surabaya. (Undergraduate Thesis). http://repository.unair.ac.id/93964/

Sakinah, R. M. N. (2017). Kajian Feminisme: 
Analisis Perbandingan Ideologi "Cantik" Tokoh Perempuan Pada Dua Chick-lit; The Debutante Divorcéé (Janda-Janda Gres) Karya Plum Sykes dan Test Pack Karya Ninit Yunita. AlTsaqafa: Jurnal Ilmiah Peradaban Islam, 2(5), 255. https://journal.uinsgd.ac.id/index.php/ja t/article/view/2008/1412

Sukmawati, L., Sudardi, B., \& Susanto, D. (2017). Perempuan Sasak Dalam Novel Sri Rinjani Karya Eva Nourma: Kajian Feminisme. Haluan Sastra Budaya, 1(2), 162. https://doi.org/10.20961/hsb.v1i2.1519 4

Sulastri, S., \& Alimin, A. A. (2017). Nilai Pendidikan Karakter Kerja Keras Dalam Novel 2 Karya Donny Dhirgantoro. Jurnal Pendidikan Bahasa, 6(2), 156168.

https://journal.ikippgriptk.ac.id/inde x.p $\mathrm{hp} /$ bahasa/article/view/619

Wati, S.L., \& Sumartini, S. (2019). Perjuangan Tokoh Ibu Mengupayakan Pendidikan Anak Perempuannya dalam Novel Katak dalam Tempurung Karya Josephine Chia: Kajian Kritik Sastra Feminis. Jurnal Sastra Indonesia, 8(3), 173-187.

https://journal.unnes.ac.id/sju/index.ph $\mathrm{p} / \mathrm{jsi} /$ article/view/28106

Susanti, E. (2013). Analisis Ketidakadilan Gender Pada Tokoh Perempuan Dalam Novel "Kupu-Kupu Malam" Karya Achmad Munif. Jurnal Artikulasi, 10(2), 713-723. http://ejournal.umm.ac.id/index.php/jib/ article/view/1251

Susanto, N. H. (2015). Tantangan Mewujudkan Kesetaraan Gender dalam Budaya Patriarki. Jurnal Muwazah, 7(2), 120-130. http://ejournal.iainpekalongan.ac.id/index.php/ Muwazah/article/view/517

Wahyuningtiyas, S. H. (2019). Upaya Tokoh
Perempuan dalam Penyelesaian Permasalahan Kemanusiaan dalam Novel Bidadari Bermata Bening Karya Habiburrahman El Shirazy. Prosiding SENASBA (Seminar Nasional Bahasa dan Sastra) 67-78. http://researchreport.umm.ac.id/index.php/SENASBA SA/article/view/2589

Zakaria, S. (2014). Perbandingan Konsep Kepemimpinan Perempuan Menurut Pandangan Tokoh Aisyiyah Dan Tokoh Feminisme Di Kota Malang. (Undergraduate Thesis). http://eprints.umm.ac.id/id/eprint/2860 1 